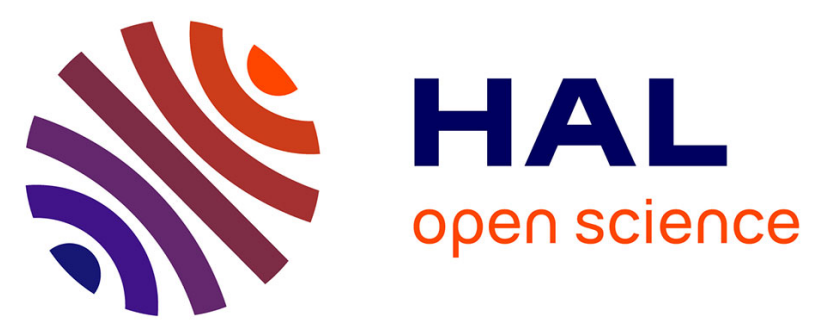

\title{
Smart foams: Switching reversibly between Ultrastable and Unstable foams
}

\author{
Anne-Laure Fameau, Arnaud Saint-Jalmes, Janine Emile, Fabrice Cousin, \\ François Boué, Bruno Novales, Jean-Paul Douliez
}

\section{- To cite this version:}

Anne-Laure Fameau, Arnaud Saint-Jalmes, Janine Emile, Fabrice Cousin, François Boué, et al.. Smart foams: Switching reversibly between Ultrastable and Unstable foams. 9. European conference on foams, Emulsions and Applications, EUFOAM 2012, Jul 2012, Lisbonne, Portugal. 1 p., 2012. hal02807263

\section{HAL Id: hal-02807263 \\ https://hal.inrae.fr/hal-02807263}

Submitted on 6 Jun 2020

HAL is a multi-disciplinary open access archive for the deposit and dissemination of scientific research documents, whether they are published or not. The documents may come from teaching and research institutions in France or abroad, or from public or private research centers.
L'archive ouverte pluridisciplinaire HAL, est destinée au dépôt et à la diffusion de documents scientifiques de niveau recherche, publiés ou non, émanant des établissements d'enseignement et de recherche français ou étrangers, des laboratoires publics ou privés. 


\title{
OD6.1
}

\section{SMART FOAMS: SWITCHING REVERSIBLY BETWEEN ULTRASTABLE AND UNSTABLE FOAMS}

\author{
Anne-Laure Fameau (1), Arnaud Saint-Jalmes (2), Fabrice Cousin (3), François Boué (3), Janine \\ Emile (2), Bruno Novales (1) and Jean-Paul Douliez (1) \\ 1. Biopolymères Interactions Assemblages INRA Nantes, France. \\ 2. Institut Physique de Rennes, Université Rennes 1, France. \\ 3. Laboratoire Léon Brillouin, CEA Saclay, France. \\ anne-laure.fameau@nantes.inra.fr
}

We have studied the foaming properties of multilayer tubular structures made of ethanolamine salt of 12-hydroxy stearic acid [Fameau, 2010]. By visual observations, we have demonstrated that these tube solutions produced foams outstandingly stable over months at room temperature (Figure 1.a). We used thin film pressure balance, small angle neutron scattering and neutron reflectivity in order to understand the key mechanisms at the origin of the stability. We have shown that those hydroxyl fatty acids quickly go to the interface but also produce solid layers preventing coalescence and coarsening. In addition, the tubes lead to large menisci surrounding the lamella and reduce the drainage flows. Thus, these tubes solution combines the advantages of both solid particles and the low molecular weight surfactants, since this system foams easily and does not coarsen nor collapse because of an optimal arrangement of monomers and tubes within the foam structure. Upon heating, tubes transit to micelles at a given temperature, what yields a very fast foam destabilization. Of particular interest is that the transition of tubes into micelles inside the foam is reversible. The foam stability can then be readily tuned to weak foam stability by simply changing the polymorphism of the system upon heating (Figure 1.b) [Fameau, 2011]. We showed how the macroscopic features as a function of the temperature depend on properties of the supramolecular assemblies in bulk. To our knowledge, such foam lifetimes obtained using low molecular weight amphiphiles are unprecedented and such foams are the first that we can switch reversibly between ultrastable and unstable in only few degrees.
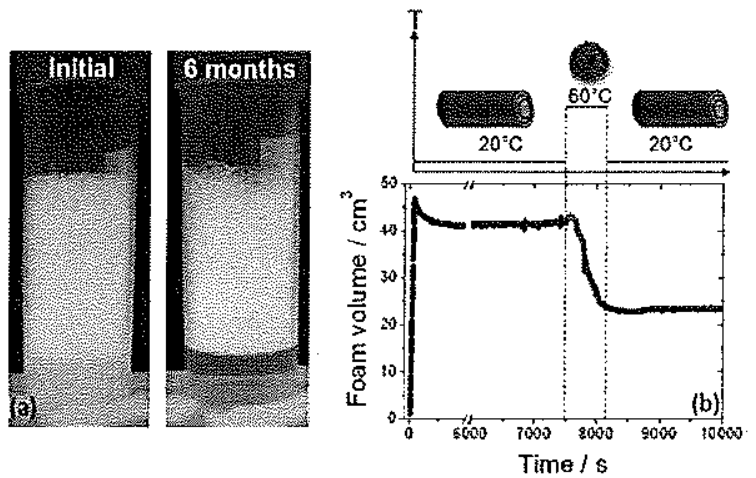

Figure 1: (a) Photos of foams taken at different times. (b) Evolution of the foam volume as a function of time and temperature.

\section{References}

Fameau et al, Journal of Colloid and Interface Science, 341:38-47, 2010.

Fameau et al, Angewandte Chemie International Edition, 50:8264-8269, 2011 